\title{
An Overview: The Toxicity of Ageratina adenophora on Animals and Its Possible Interventions
}

\author{
Zhihua Ren $^{\dagger}$, Samuel Kumi Okyere ${ }^{\dagger} \mathbb{D}$, Juan Wen, Lei Xie, Yujing Cui, Shu Wang, Jianchen Wang, \\ Suizhong Cao $\mathbb{D}$, Liuhong Shen, Xiaoping Ma $\mathbb{D}$, Shumin Yu, Junliang Deng and Yanchun Hu *
}

check for

updates

Citation: Ren, Z.; Okyere, S.K.; Wen, J.; Xie, L.; Cui, Y.; Wang, S.; Wang, J.; Cao, S.; Shen, L.;

$\mathrm{Ma}, \mathrm{X}$.; et al. An Overview: The Toxicity of Ageratina adenophora on Animals and Its Possible

Interventions. Int. J. Mol. Sci. 2021, 22, 11581. https://doi.org/10.3390/ ijms222111581

Academic Editor: Rosaria Acquaviva

Received: 14 September 2021

Accepted: 24 October 2021

Published: 27 October 2021

Publisher's Note: MDPI stays neutral with regard to jurisdictional claims in published maps and institutional affiliations.

Copyright: (c) 2021 by the authors. Licensee MDPI, Basel, Switzerland. This article is an open access article distributed under the terms and conditions of the Creative Commons Attribution (CC BY) license (https:/ / creativecommons.org/licenses/by/ $4.0 /)$.
Key Laboratory of Animal Diseases and Environmental Hazards of Sichuan Province, College of Veterinary Medicine, Sichuan Agricultural University, Chengdu 611130, China; zhihua_ren@126.com (Z.R.); samuel20okyere@gmail.com (S.K.O.); juanwen881010@163.com (J.W.); wsxielei@gmail.com (L.X.); yjchoi@163.com (Y.C.); shuw0326@163.com (S.W.); wangjianchen01@163.com (J.W.); suizhongcao@126.com (S.C.); shenlh@sicau.edu.cn (L.S.); mxp886@sicau.edu.cn (X.M.); yayushumin@163.com (S.Y.); dengj1213@126.com (J.D.)

* Correspondence: yanchunhu@sicau.edu.cn; Tel.: +86-28-8629-1162

+ Authors contributed equally to this work and must be considered as first co-authors.

\begin{abstract}
Ageratina adenophora is one of the major invasive weeds that causes instability of the ecosystem. Research has reported that $A$. adenophora produces allelochemicals that inhibit the growth and development of food crops, and also contain some toxic compounds that cause toxicity to animals that consume it. Over the past decades, studies on the identification of major toxic compounds of $A$. adenophora and their toxic molecular mechanisms have been reported. In addition, weed control interventions, such as herbicides application, was employed to reduce the spread of A. adenophora. However, the development of therapeutic and prophylactic measures to treat the various $A$. adenophora-induced toxicities, such as hepatotoxicity, splenotoxicity and other related disorders, have not been established to date. The main toxic pathogenesis of $A$. adenophora is oxidative stress and inflammation. However, numerous studies have verified that some extracts and secondary metabolites isolated from $A$. adenophora possess anti-oxidation and anti-inflammation activities, which implies that these extracts can relieve toxicity and aid in the development of drug or feed supplements to treat poisoning-related disorders caused by A. adenophora. Furthermore, beneficial bacteria isolated from rumen microbes and $A$. adenophora can degrade major toxic compounds in A. adenophora so as to be developed into microbial feed additives to help ameliorate toxicity mediated by $A$. adenophora. This review presents an overview of the toxic mechanisms of $A$. adenophora, provides possible therapeutic strategies that are available to mitigate the toxicity of $A$. adenophora and introduces relevant information on identifying novel prophylactic and therapeutic measures against A. adenophora-induced toxicity.
\end{abstract}

Keywords: Ageratina adenophora; toxicity; mechanisms; possible interventions; antioxidant; antiinflammation; probiotics

\section{Introduction}

Ageratina adenophora is one of the widely known invasive weeds that negatively affects the livestock production industry [1,2]. A. adenophora is highly toxic to various animals and affect multiple organs; hence, it has raised serious health concerns in many countries [3,4]. For example, a study reported that the ingestion of $A$. adenophora caused respiratory disease in horses, characterized by acute edema of the lungs, which led to death [5]. Verma et al. [6] also found that $A$. adenophora reduced digestive function and photosensitive reaction in cattle. Freeze-dried leaf powder and methanol extract of $A$. adenophora caused multiple focal parenchymal necrosis and degeneration in the liver of mice [7]. Rats fed with a basal diet containing 25\% (w/w) freeze-dried $A$. adenophora leaf powder showed signs of jaundice, characterized by an elevation of plasma bilirubin, ALP, ALT and AST levels [8]. 
Furthermore, the toxic effects of $A$. adenophora ingestion on the liver, spleen and kidney of goat and mice have also been reported, with dose-dependent apoptosis and autophagy and disorders, such as cholestasis, bile duct hyperplasia, liver necrosis, swelling and bleeding in the spleen and kidneys [9-11]. In addition, $\geq 20 \%$ dose of $A$. adenophora increased liver weight, induced severe inflammation, increased reactive oxygen species (ROS) production, and activated pyroptosis [3]. Mice fed with $175 \mathrm{mg} / \mathrm{kg}$ A. adenophora extract had decreased antioxidant function by reducing the activities of SOD, CAT, and GSH, while increasing the levels of lipid peroxide (LPO) in the liver [12]. A. adenophora caused a disorder in the arrangement and inhibited the activities of the splenocytes and immune cells in mice [13]. This shows that $A$. adenophora induces oxidative stress in the liver, thereby damaging it [14].

\section{Invasive Nature of $A$. adenophora}

A. adenophora was first introduced into the Yunan province from the China-Burma border in 1940 [15], and eventually spread to Sichuan, Guangxi, Guizhou, Hubei and Tibet provinces, the Chonqing municipality and even to Taiwan [16]. A. adenophora is one of the most important invasive plant species in China [17]. It tops the list of China's first foreign invasive species released by the State Environmental Protection Administration and the Chinese Academy of Sciences, and currently affects over 30 million hectares of arable land [18]. It is predicted to spread further northward and eastward at an average speed of $20 \mathrm{~km} /$ year [16]. A. adenophora is native to Mexico and Costa Rica and has successfully invaded habitats across the world $[19,20]$. A. adenophora is normally found in roadsides, pastures, fence lines, waste areas and riparian zones as well as urban open spaces, open woodlands and forest margins in subtropical and warmer temperate regions [21]. Its rapid spread is due to its allelopathic competition with other plant species [22]. It was first reported in Australia in 1904 and has spread along the shorelines of New South Wales and southern Queensland [23]. The plant is documented as a weed in 10 states of the United States of America. In addition, A. adenophora was ranked as a Class 4 Noxious Weed under the NSW Noxious Weeds Act of 1993 [24]. It was tagged as an invasive weed species, due to its wide distribution in many continents, such as Asia, Africa, America and Europe [21,25].

\section{Major Toxins in A. adenophora and Their Toxic Nature}

The structure and function of the liver and spleen make them highly susceptible to pathogen and toxin destruction [26].

Numerous sesquiterpenes were identified in A. adenophora of which most have the same molecular skeleton as cadinene. Among these sesquiterpenes, 9-oxo-10, 11-dehydroagerophorone (euptox A), 2-deoxo-2-(acetyloxy)-9-oxo-ageraphorone (DAOA) and 9-oxoagerophorone (OA) are the major toxic compounds found in A. adenophora (Figure 1). The main differences between the molecular structure of DAOA and OA is the presence of a 2-acetoxy group in the DAOA and 2-carbonyl group in OA, whereas the distinguishing feature between euptox $\mathrm{A}$ and $\mathrm{OA}$ is the presence or absence of an unsaturated 6-11 bond in conjugation with a 7-oxo function [27]. These toxins are mainly found in the leaves with a mass percentage of $0.63-1.99 \%$ in dry leaves [28]. 9-Oxo-10, 11-dehydroagerophorone (euptox A) exhibited hepatotoxicity in rodents $[7,29-31]$ with a median lethal dose (LD50) of $1470 \mathrm{mg} / \mathrm{kg}$ body weight of mice, whereas 2-deoxo-2-(acetyloxy)-9-oxoageraphorone(DAOA) and 9-oxo-agerophorone (OA) also showed hepatotoxicity in mice with respective LD50 of $926 \mathrm{mg} / \mathrm{kg}$ BW and $1470 \mathrm{mg} / \mathrm{kg}$ BW [27]. DAOA and euptox A are also immunotoxic to mice, showing characteristics such as reduction in numbers and irregular arrangement of splenocytes and thymocytes [13]. Euptox A can cause the arrest of splenocyte proliferation in the G0/G1 phage and induce autophagy in a dose-dependent manner when administered to mice via the gastric route [31]. A. adenophora is dangerous to animals because of its toxic nature; hence, there is the need to develop control strategies and also establish therapeutic measures to attenuate its toxicity once ingested into the body. 
<smiles>CC1=C[C@@H]2C(=C(C)C)C(=O)C[C@@H](C)[C@]2(C)CC1=O</smiles>

9-oxo-10,11-dehydro-ageraphorone(DAO)

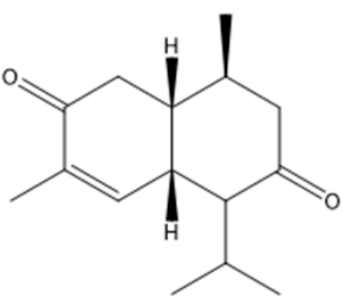

9-oxo-ageraphorone(OA)

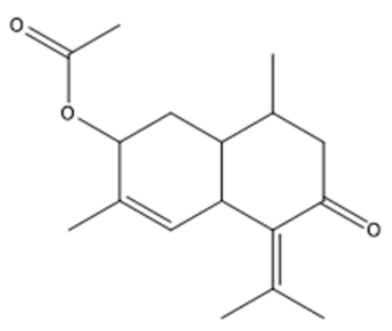

2-deoxo-2-(acetyloxy)-)9-oxoageraphorone(DAOA)

Figure 1. Structure of major toxins compounds in A. adenophora.

\section{Molecular Mechanism of $A$. adenophora Toxicity}

The exposure of animals to $A$. adenophora causes an elevation in reactive oxygen species (ROS) parameters, such as nitric oxide, superoxide and hydroxyl radicals, leading to the damage of DNA and proteins in addition to altering the cellular architecture, permeability and cell survival [32,33]. A. adenophora is reported to trigger a series of downstream signaling cascades and further interrupt signaling pathways associated with cell growth, proliferation and apoptosis [3]. The mechanism of ROS formation by A. adenophora is yet to be thoroughly decoded. However, several studies have indicated the involvement of mitochondrial complex I in A. adenophora-mediated oxidative stress in different types of cells. The presence of $A$. adenophora in cells results in DNA damage, due to its ROSforming ability through interactions with oxygen [3]. A. adenophora also causes toxicity by reducing the mitochondria membrane potential and through the release of cytosol from the mitochondria membrane [29]. Furthermore, A. adenophora causes an imbalance of apoptosis-related enzymes, $\mathrm{Bax}$ and $\mathrm{BCl}_{2}$, which causes the activation of caspases, thereby resulting in DNA fragmentation and apoptosis.

A. adenophora causes mitochondria dysfunction through the reduction of the cellular antioxidant systems, such as glutathione (GSH), and nicotinamide adenine dinucleotide phosphate (NADPH) levels, which may also disrupt the maintenance of the reduced states of thiol-containing proteins in the mitochondria. This causes the oxidation of the thiol-containing proteins, which in turn, changes the conformation of the mitochondrial membrane permeability transition pore, causing its opening, thereby promoting apoptosis and necrosis [34]. Therefore, at the cellular level, it can be concluded that $A$. adenophora triggers necrotic cell death, leading to multiple organ failure.

A. adenophora can induce an extensive inflammatory response [35]. Increased levels of ROS are associated with various diseases, such as chronic inflammation [36], and this promotes the release of various pro-inflammatory factors [37]. A. adenophora was reported to cause pyroptosis in the spleen of mice at the dose of $10 \%$ and above [14]. Pyroptosis involves the inflammatory response of pro-inflammatory cytokines, such as caspase-1 activation and interleukin-1 $\beta$ (IL-1 $\beta$ ) production [38-40]. Caspase-1 protease, a major constituent of the multiprotein inflammasome complexes, is involved in the activation and secretion of IL-1 $\beta$, a pro-inflammatory cytokine [41]. Numerous studies have reported that pyroptosis is an immune effector mechanism that occurs in various types of cells [42,43] and is activated by diverse pathological stimuli [44,45], leading to the secretion of proinflammatory cytokines [46]; however, the underlying mechanism for this occurrence requires further studies.

Another current research reported that $A$. adenophora causes toxicity in the spleen by destroying the fibroblastic reticular cell (FRC) network and causing an imbalance in the Th1Th2 cell ratio [33]. The study speculated that $A$. adenophora ingestion induces a persistent inflammatory response in the spleen, which in turn could lead to the activation and promotion of $\mathrm{T}$ cell immunity, resulting in splenic dysfunction. However, the mechanism behind these observations is not yet clear. Therefore, it requires further studies. Another study by Cui et al. [47] also reported that $A$. adenophora causes destruction of the intestinal 
structure and immune barrier integrity. In summary, A. adenophora induces inflammation in cells, which leads to cell death mediated by pyroptosis. Figure 2 depicts the molecular mechanisms of $A$. adenophora-induced toxicity in various organs.

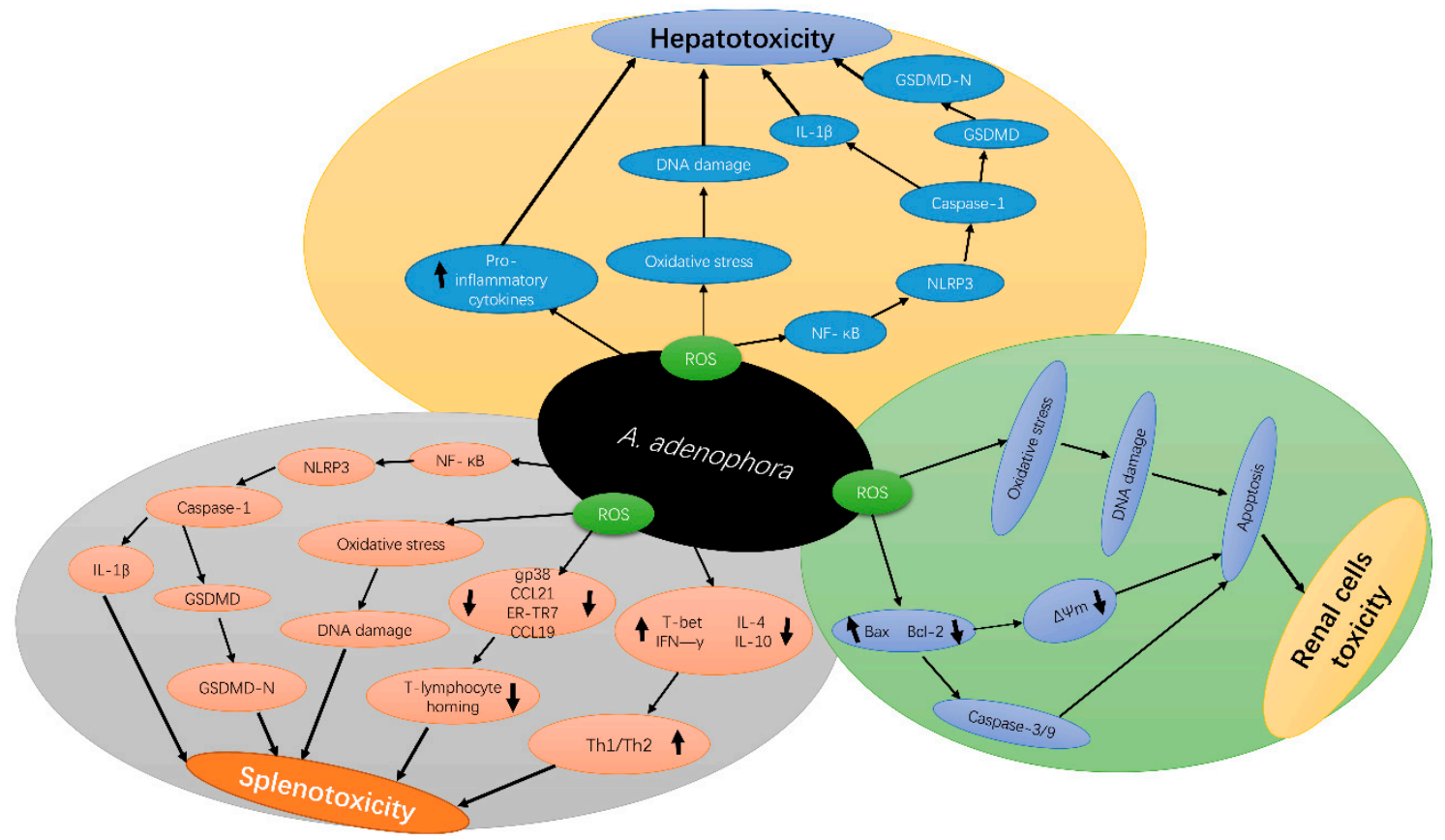

Figure 2. Schematic diagram of A. adenophora-induced toxicity in the liver, spleen and kidney and its underlying molecular mechanisms A. adenophora causes liver toxicity via the ROS apoptotic pathway, pro-inflammation mediated pathway, ROSNLRP3-mediated pyroptosis pathway, and caspase-1-dependent pyroptosis pathway, A. adenophora causes spleen toxicity via ROS apoptotic pathway, ROS-NLRP3-mediated pyroptosis pathway, caspase-1-dependent pyroptosis pathway, destroying the Fibroblast reticulocyte (FCR) network and elevating Th1/Th2 ratio, Finally A. adenophora causes toxicity of the kidney via ROS apoptosis pathway, caspase 3/9 mediated pathway and mitochondria dysfunction pathway. IL-1 $\beta$-Interleukin 1-beta, ROS—reactive oxygen species, GSDMD—gasdermin D, NLRP3-NOD-, LRR- and pyrin domain-containing protein 3, NFkB-Nuclear factor- $\mathrm{kB}, \Delta \Psi \mathrm{m}$-Mitochondria potential membrane, gp38-glycoprotein 38, Th1/2-T-helper cells 1 and 2, CCL21-C-C Motif Chemokine Ligand 21, CCL19-C-C Motif Chemokine Ligand 19, T-bet-T-box transcription factor 21,

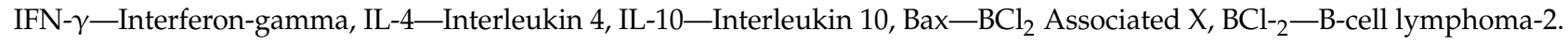

\section{Pharmacological Applications of A. adenophora and Potential Therapeutic Interventions against Its Toxicity}

A. adenophora is used in the traditional system of medicine across the world. In India, leaves of the plant are pharmacologically regarded as astringent, thermogenic, stimulants and are used as medicine because of the antimicrobial, antiseptic, blood coagulating, analgesic, and antipyretic properties [48]. Furthermore, a decoction of the plant is recommended for treating jaundice and ulcers [49]. In Nigerian traditional medicine, it is used to treat fever, diabetes, and inflammation [50]. These pharmacological properties may be the result of bioactive secondary metabolites present in the plant. A study by Fu et al. [51] recently reported that two metabolites, phomoxanthone $\mathrm{A}$ and penialidin A produced by a fungal endophyte Coniochaeta sp. F-8, isolated from A. adenophora, showed antioxidant activities, and hence, had great importance in biotechnology as a source of novel bioactive compounds for antioxidant drug development. Moreover, another study reported antiviral activity of euptox A in NDV-infected chicken embryo fibroblasts (CEFs), using the MTT method [52]. The results showed that euptox A at $10 \mu \mathrm{g} / \mathrm{mL}$ could directly suppress, neutralize, and block NDV in vitro as well as prevent the binding of NDA to its receptor. Nong et al. [53] also reported the acaricidal activity of ethanol extract from leaves of A. adenophora. A study by Rajeswary et al. [54] reported that crude extracts derived from $A$. adenophora had ovicidal effects against mosquito eggs at concentrations of $300 \mathrm{mg} / \mathrm{L}$; hence, the plant 
could be used for controlling mosquitos. Numerous studies have showed antimicrobial activity of A. adenophora and its extracts [48]. A study reported that $A$. adenophora inhibited Phytophthora capsici at $50-250 \mathrm{mg} / \mathrm{mL}$ concentrations [55]. Another study also reported that oils extracted from A. adenophora showed significant toxicity against Erwinia herbicola and Pseudomonas putida, two phyto-pathogenic bacteria at concentrations of $0.25-5 \mu \mathrm{L} \mathrm{mL}^{-1}$ [56]. Both organic and aqueous crude extracts from leaves of $A$. adenophora showed inhibitory effects on the growth of Bacillus subtilis, Bacillus cereus and Pseudomonas aeruginosa [57]. Furthermore, methanolic leaf extract from $A$. adenophora showed an obvious inhibitory effect on Pseudomonas aeruginosa [58]. Euptox A also showed potent effects against the widespread plant pathogen Ralstonia solanacearum (R1-4), with the minimum inhibitory dose ranging from 0.25 to $1 \mathrm{mg} / \mathrm{mL}$ [59]. The thymol derivatives of $A$. adenophora have shown inhibitory effects against both Gram-negative and Gram-positive bacteria [60].

A number of secondary metabolites isolated from the inflorescence and roots of A. adenophora, mainly sesquiterpenes, showed potent antifungal activity [48]. Several studies have reported the inhibitory effects of the crude extracts of $A$. adenophora against pathogenic fungi [61,62]. For example, $100.00 \mathrm{mg} / \mathrm{mL}$ A. adenophora ethanol, acetone, and ether extract showed $100 \%$ inhibitory rate against Fusarium gramincarum and Colletotrichum glycines Hori [63]. In addition, Liu et al. [64] reported that the leaf extracts of $A$. adenophora (mainly $10 \mathrm{H} \beta$-9-oxo-agerophorone, $10 \mathrm{H} \alpha$-9-oxo-agerophorone and euptox A) inhibited the formation of Pythium myriotylum mycelial biomass at the minimum inhibitory concentration of $100 \mu \mathrm{g} / \mathrm{mL}$. Euptox A also inhibited germination of Fusarium oxysporum, Bipolaris sorokiniana, Fusarium proliferatum and Alternaria tenuissima as well as spore production in Fusarium oxysporum and Bipolaris sorokiniana [65]. In the latest study of $\mathrm{Hu}$ et al. [66], it was found that both euptox A and cadinan-3-ene-2,7-dione (CED) isolated from the methanol extract of $A$. adenophora showed antifungal activities characterized by the destruction of the integrity of cell membranes and inhibition of ergosterol synthesis, which eventually led to fungal cell death. The oil extract from A. adenophora inhibited the mycelial growth of Phytophthora capsici at the concentration of $500 \mu \mathrm{g} / \mathrm{mL}$ after 7 days of incubation [67]. Furthermore, in recent years, the use of $A$. adenophora as an anti-nematode agent and an insecticide was recognized. A recent study by Lin et al. [68] reported a stronger resistance of $A$. adenophora to Aphis gossypii feeding. The methanol extract of $A$. adenophora showed good toxicity to radish aphids, and also had a certain inhibitory effect on the growth and development of Mythimna separata. The acetone extract of A. adenophora had a toxic effect against cabbage aphids and Brevicoryne brassicae [69]. Similar results were observed by Wang [70] on Aphis gossypii.

Furthermore, anti-cancer/tumor properties of $A$. adenophora were reported in recent studies. For example, a study by André et al. [71] reported that euptox A isolated from A. adenophora showed a strong potential against cancer by acting on cancer targeted cellular characteristics. Similarly, Liao et al. [72] also studied the antitumor activity of euptox A isolated from A. adenophora in vitro against three cell lines, using the 4,5-dimethylthiazol-2yl)-2,5-diphenyltetrazolium bromide (MTT) assay. The results showed that euptox A had significant antitumor activity against the three tumor cell lines in vitro in a dose-dependent manner. Euptox A percentage inhibition on the human lung cancer A549 cells, Hela cells, and Hep-2 cells were $76.42 \%, 68.30 \%$ and $79.05 \%$, respectively, at a concentration $500 \mu \mathrm{g} / \mathrm{mL}$, whereas the $50 \%$ inhibitory concentration (IC50) of euptox A for the three tumor cell lines were $369 \mu \mathrm{g} / \mathrm{mL}, 401 \mu \mathrm{g} / \mathrm{mL}$ and $427 \mu \mathrm{g} / \mathrm{mL}$ (A549, Hela and Hep-2 cells, respectively). Another study by Chen et al. [73] reported that essential oil from A. adenophora promoted HCC (hepatocellular carcinoma) apoptosis by activating the mitochondria and endoplasmic reticulum apoptotic signaling pathways as well as inhibiting the action of STAT3 (signal transducer and activator of transcription 3) and AKT (protein kinase B).

Other important pharmacological activities of A. adenophora, such as its anti-pyretic, analgesic and wound healing abilities, were reported recently. Ringmichon and Gopalkrishnan [74] reported that the aqueous extracts at doses of 300 and $400 \mathrm{mg} / \mathrm{kg}$ body weight showed a significant decrease in pyretic temperature a few hours after treatment, which 
was similar to the standard drug (paracetamol; $150 \mathrm{mg} / \mathrm{kg}$ body weight). The methanolic extract of $A$. adenophora leaves showed significant analgesic activity as compared to standard drugs, diclofenac sodium and pentazocine, in an acetic acid-induced writhing test, tail immersion test, and tail-flick test models [75]. Finally, Kumar et al. [76] investigated the wound healing properties of ethanolic extract of $A$. adenophora formulated as a gel, using the excision and incision wound models. The results showed that the gel could strongly heal the wound in excision with $90.98 \%$ wound contraction and $36.16 \%$ reduction in epithelialization time, whereas in the incision model, the gel significantly increase $(37.86 \%)$ the tensile strength on the 13th day of treatment when compared to pure gel control. In a nutshell, A. adenophora produces bioactive compounds that exhibit pharmacological activities and therefore, could be adopted to develop potential drugs or feed supplements to prevent or treat health complications caused by A. adenophora toxicity. Therefore, some potential therapeutic drug candidates (plant extracts, secondary metabolites, and bacteria) from A. adenophora and other sources that could be used to treat or prevent the two major pathogeneses (oxidative stress and inflammation) of $A$. adenophora toxicity includes the following.

\subsection{Anti-Oxidant Therapeutic Candidates for A. adenophora Toxicity}

Although many studies have reported on the toxic effects of A. adenophora, other studies have also reported on the plant's beneficial biological activities, such as its antioxidant, anti-inflammation, anti-microbial, anti-obesity, anticancer and anti-tumor qualities $[71,75,77]$. These beneficial activities induced by A. adenophora could be attributed to the presence of bioactive compounds in this plant [22]. Oxidative stress is one of the major pathogeneses for A. adenophora toxicity; therefore, the use of antioxidants, especially from natural products, could help eliminate the toxic effects induced by this plant. Numerous bioactive extracts and secondary metabolites in A. adenophora were reported to possess antioxidant properties. For example, ethanolic extract from the leaves of $A$. adenophora was reported to reduce the generation of hydroxyl radicals [22]. Furthermore, the quinic acid derivative, including 5-O-trans-o-coumaroylquinic acid methyl ester, chlorogenic acid methyl ester, macranthoin $\mathrm{F}$ and macranthoin $\mathrm{G}$ isolated from the leaves of the plant, showed antioxidant activity against DPPH (1, 1-diphenyl-2-picrylhydrazyl) radical [78]. Another study that used 2, 2-diphenyl-1-picrylhydrazyl (DPPH) radical scavenging protocol and the ferric reducing ability assay (FRAP) reported that essential oils and cadences extracted from the leaves of $A$. adenophora showed antioxidant activity similar to the test standards [12]. In addition, oil extracts from $A$. adenophora showed antioxidant activity, with IC50 values of 8.3 and $4.2 \mu \mathrm{L}$, after being tested using the DPPH and $\beta$-carotene bleaching methods, respectively [22]. Lastly, methanolic extracts from A. adenophora showed significant DPPH activity as compared to the standard butylated hydroxyl toluene (IC50 for A. adenophora was 92.791, whereas that for butylated hydroxyl toluene was 68.043) [79]. Therefore, harnessing these extracts and secondary metabolites into antioxidant drugs or feed supplements to reduce the ROS damages induced by A. adenophora and other toxins could play an important role in reducing the toxicity of this plant as well utilizing the plant's resources for the benefit of mankind. However, even though various studies have reported the antioxidant properties of some extracts and secondary metabolites from A. adenophora, there is still the need for effective clinical studies and monitoring to ascertain the safest dose concentration and periods for administration before drug development. Other potential antioxidant agents that could be adopted to reduce the oxidative stress mediated toxicity induced by A. adenophora are shown in Table 1. 
Table 1. Potential antioxidant and anti-inflammatory agents for treatment of A. adenophora-induced toxicity.

\begin{tabular}{|c|c|c|c|c|c|}
\hline & Antioxidant Agents & Animal Model & Dosage & Activities & Reference \\
\hline 1 & $\begin{array}{l}\text { Quercetin and vitamin E } \\
\text { combination }\end{array}$ & Chicken & $\begin{array}{l}0.4 \mathrm{~g} / \mathrm{kg} \text { and } 0.2 \mathrm{~g} / \mathrm{kg} \\
\text { respectively for } \\
10 \text { weeks }\end{array}$ & $\begin{array}{c}\text { Reduce ROS } \\
\text { Increase total antioxidant } \\
\text { capacity (T-AOC) } \\
\text { Reduce pro-inflammation } \\
\text { cytokines }\end{array}$ & [80] \\
\hline 2 & Resveratrol & Mice & $\begin{array}{l}40 \mathrm{mg} / \mathrm{kg} \text { for } \\
6 \text { months }\end{array}$ & $\begin{array}{c}\text { Reduce ROS } \\
\text { Reduce pro-inflammation } \\
\text { cytokines }\end{array}$ & [81] \\
\hline 3 & Lycopene & Rat & $\begin{array}{c}10 \text { and } 20 \mathrm{mg} / \mathrm{kg} \text { for } \\
30 \text { days }\end{array}$ & $\begin{array}{c}\text { Reduce ROS } \\
\text { Reduce pro-inflammation } \\
\text { cytokines (IL-6, IL-1 } \beta, \text { TNF- } \alpha \text { ) }\end{array}$ & [82] \\
\hline 4 & Glycine Nano-selenium & Rats & $\begin{array}{l}0.05 \text { and } 0.1 \mathrm{mg} / \mathrm{kg} \text { for } \\
30 \text { days }\end{array}$ & Decrease the MDA levels & [83] \\
\hline 5 & Alfalfa saponins & IEC-6 cells & $\begin{array}{l}75,100,150,200 \text { and } \\
300 \mu \mathrm{mol} / \mathrm{L} \text { for } 24 \mathrm{~h}\end{array}$ & $\begin{array}{l}\text { Elevate the amount of T-AOC in } \\
\text { cells }\end{array}$ & [84] \\
\hline 6 & $\begin{array}{l}\text { Malus doumeri leaf } \\
\text { flavonoids }\end{array}$ & $\begin{array}{c}\text { human } \\
\text { embryonic } \\
\text { kidney } 293 \mathrm{~T} \\
\text { cells }\end{array}$ & $160 \mu \mathrm{g} / \mathrm{mL}$ for $48 \mathrm{~h}$ & $\begin{array}{l}\text { Increase the levels of catalase } \\
\text { (CAT), superoxide dismutase } \\
\text { (SOD), glutathione (GSH), and } \\
\text { glutathione peroxidase } \\
\text { (GSH-Px) and reduce the level } \\
\text { of malondialdehyde (MDA) }\end{array}$ & [85] \\
\hline 7 & Oregano essential oil & $\begin{array}{l}\text { RAW264.7 } \\
\text { Cells }\end{array}$ & $2.5-10 \mu \mathrm{g} / \mathrm{mL}$ for $24 \mathrm{~h}$ & $\begin{array}{l}\text { Inhibited the mRNA expression } \\
\text { of IL-1 } \beta \text {, IL-6, and TNF- } \alpha \text { in the } \\
\text { RAW264.7 cells }\end{array}$ & [86] \\
\hline 8 & Ergosterol & $\begin{array}{l}16 \mathrm{HBE} \text { cells } \\
\text { and Balb/c } \\
\text { mice }\end{array}$ & $\begin{array}{c}\text { 5, } 10 \text { and } 20 \mu \mathrm{M} \text { for } 24 \\
\mathrm{~h} \text { and } 40 \mathrm{mg} / \mathrm{kg} \text { for } \\
21 \text { days }\end{array}$ & $\begin{array}{l}\text { Decrease the expression of } \\
\text { interleukin- } 6 \text { (IL-6), tumor } \\
\text { necrosis factor } \alpha \text { (TNF- } \alpha \text { ), }\end{array}$ & [87] \\
\hline 9 & Ginger & $\begin{array}{l}\text { Pulmonary TB } \\
\text { patients } \\
\text { (human) }\end{array}$ & $\begin{array}{l}3 \mathrm{~g} \text { of ginger extract } \\
\text { daily for } 1 \text { month }\end{array}$ & $\begin{array}{l}\text { Reduced the levels of tumor } \\
\text { necrosis factor (TNF) alpha }\end{array}$ & [88] \\
\hline 10 & Selenium & Chicken & $1 \mathrm{mg} / \mathrm{kg}$ for 12 weeks & $\begin{array}{c}\text { Reduced the levels of } \\
\text { inflammation-related factors } \\
\text { (Nuclear factor-kappa B, tumor } \\
\text { necrosis factor- } \alpha, \\
\text { cyclooxygenase-2, NLRP3, } \\
\text { apoptosis-associated speck-like } \\
\text { protein containing a caspase } \\
\text { recruitment domain, caspase- } 1 \text {, } \\
\text { interleukin (IL)-1 } \beta, \text { IL- } 6 \text {, IL-18 } \\
\text { and interferon- } \gamma \text { ) }\end{array}$ & [89] \\
\hline 11 & $\begin{array}{c}\text { Probiotics } \\
\text { (Lactobacillus acidophilus, } \\
\text { Lactobacillus casei, } \\
\text { Lactococcus lactis, } \\
\text { Lactobacillus reuteri, and } \\
\text { Saccharomyces boulardii) }\end{array}$ & $\begin{array}{l}\text { Human colon } \\
\text { epithelial } \\
\text { HT-29 cells }\end{array}$ & $10^{8} \mathrm{CFU} / \mathrm{mL}$ for $18 \mathrm{~h}$ & $\begin{array}{l}\text { Reduce IL-1 } \beta, \text { IL- } 6 \text {, TNF- } \alpha \text {, and } \\
\text { increase IL-10 production } \\
\text { Increased \% of DPPH } \\
\text { scavenging activity }\end{array}$ & {$[90]$} \\
\hline
\end{tabular}

\subsection{Anti-Inflammatory Therapeutic Candidates for A. adenophora Toxicity}

As already established, inflammation remains one of the main pathogeneses of A. adenophora toxicity in cells. Therefore, the adoption and use of anti-inflammatory products to treat the toxicity of $A$. adenophora and its derivatives is a promising strategy for reducing the health complications or death in animals who have ingested this plant. The antiinflammatory activity of extracts and secondary metabolites of $A$. adenophora were reported 
in various studies. For example, the ethanolic leaf extract of $A$. adenophora showed antiinflammatory activity via the inhibition of IL1 $\beta$ and cyclooxygenase 2 (COX-2) genes [22]. In addition, a study reported that the intravenous administration of the leaf extract of $A$. adenophora increased the number of $\mathrm{CD}^{+} \mathrm{T}$ cells in the spleen, induced TGF $\beta$ encoding (a cytokine involved in tissue repair mechanism), and inhibited the expression of IL1 $\beta$ and COX-2 genes responsible for the metabolism of inflammatory mediators [91,92]. Furthermore, ethanolic extracts from the leaves of $A$. adenophora showed an anti-inflammatory role via the inhibition of hydroxyl radical generation [22,91]. In addition, the ethanolic leaf extract of $A$. adenophora was reported to suppress efficiently the inflammatory reaction set in foot paw induced by injecting dinitrofluorobenzene (DNFB) [92]. Therefore, the effective development of anti-inflammation drugs from these extracts and secondary metabolites could be a novel clinical strategy to mitigate the toxic effects of $A$. adenophora exposure. However, safe doses and administration periods require thorough research. In addition to extracts and secondary metabolites extracted from $A$. adenophora that have antiinflammatory properties, other natural products that have demonstrated anti-inflammatory activities are shown in Table 1.

\subsection{Degrading Microbes and Probiotics Therapeutic Candidates for A. adenophora Toxicity}

Micro-organisms are indispensable to the nutrition and wellbeing of the host, including humans and animals [93]. Some of these microorganisms have been reported to degrade various toxic compounds in food, soil and the environment. For example, some strains of Pseudomonas, Acinetobacter, Mycobacterium, Haemophilus, Rhodococcus, Paenibacillus, and Ralstonia were reported to encompass the metabolic pathways required for the degradation of many hydrocarbons and mycotoxins [94-96]. Similarly, some bacteria were also identified to be able to degrade some major toxins of $A$. adenophora. Stenotrophmonas spp isolated from A. adenophora could degrade euptox A, thus making A. adenophora safe to feed livestock [72]. Furthermore, a more recent study reported that tannase-producing rumen bacteria, Klebsiella variicola strain PLP G-17 LC, Klebsiella variicola strain PLP S-18 and Klebsiella pneumonia strain PLP G-17 SC could also degrade euptox A. These findings suggest that using the above microbial strains as microbial feed supplements could enhance the utilization of A. adenophora to alleviate the toxicity caused by euptox A (A. adenophora). Therefore, there is a need for further studies to isolate more such beneficial bacteria to help degrade the other main toxins (such as 2-deoxo-2-(acetyloxy)-9-oxo-ageraphorone and 9-oxo-agerophorone) in the plant. These bacteria and fungi could be developed into probiotics or other feed supplements that would be administered to animals that are highly exposed to A. adenophora and other noxious plants to prevent or reduce their toxicity. However, to achieve this, there is the need to investigate the efficacy and safety of these microbial strains through standardized experimental animal feeding trials.

Another promising therapeutic intervention for the treatment of toxicity caused by A. adenophora that has not been tested yet is the administration of probiotics. Probiotics have been reported to improve the antioxidant status and reduce inflammation in most animal species $[97,98]$. Additionally, numerous studies have reported the protective effect of probiotics in oxidative stress and inflammation induced by various toxins. For example, Lactobacillus spp was reported to reduce oxidative stress induced by deoxynivalenol (DON) via reducing the production of ROS in broiler chicken [99]. In addition, Lactobacillus salivarius BP121 was reported to decrease the inflammation and oxidative stress in cisplatin-induced acute kidney injury in rats [100]. Therefore, there is the need for advanced studies on the effects of various types of probiotic strains on the toxicity induced by A. adenophora to effectively understand the molecular bases for the treatment of A. adenophora-induced toxicity by probiotics.

\section{Discussion and Future Prospects}

Over the past years, conscious efforts have been put in place to reduce the growth and spread of A. adenophora. Various weed control strategies have been established to control 
the spread of this plant to reduce its toxic effects on the environment; however, due to the plant's growth patterns and invasive nature, all these efforts have not yielded good results so far [4]. In addition, lacking in strategies for the plants' elimination, scientists have only focused on the development of strategies to reduce the spread and distribution of this plant and the plants toxicity, without giving much attention to the therapeutics after ingestion of this plant.

Plants and plant products are used to treat numerous diseases, as they continue to serve as a potent source of new medicinal candidates, and for the treatment of emerging diseases. For example, a study by Fernández et al. [101] reported that flavonoids could provide a dual effect for the combination treatment, potentiating the antitumor effect of 5-FU, and concurrently, avert important side effects of 5-FU chemotherapy. In addition, another study reported that administration of phytocannabinoids isolated from Cannabis sativa improves the health and function of the gastrointestinal tract [102]. Freitas et al. [103] also reported that Spirulina platensis is a safe natural analgesic that displays great therapeutic activity in inflammatory pain disorders. Therefore, this review revealed extensive research on some extracts and secondary metabolites extracted from A. adenophora and other sources that could be used for the treatment of toxicity induced by $A$. adenophora through intensive investigations and clinical trials. Furthermore, a major section of this review highlighted the antioxidant and anti-inflammatory properties of the extracts, secondary metabolites and other agents that could counter the oxidative stress and inflammation-mediated toxic effects induced by A. adenophora exposure. In addition, this paper revealed some beneficial bacteria that were reported to degrade some major toxic molecules released by $A$. adenophora, and suggested the adoption of probiotics in treating $A$. adenophora toxicity as a promising therapeutic strategy since numerous probiotic strains have been reported to have antioxidant and anti-inflammatory properties [97]. In summary, this review seeks to bring awareness to the scientific community on the potential utilization of A. adenophora plant resources (extracts, secondary metabolites and endophytes) and other promising agents as useful products (such as dietary supplements or drug candidates) to prevent or treat the toxic effects associated with $A$. adenophora and other toxic plant intoxication. This field remains wide open for exploration of natural product formulations and genetic manipulations that can not only offer protection against $A$. adenophora-mediated toxicity, but also can serve as a therapeutic measure to reverse the toxic effects induced by A. adenophora.

Author Contributions: Z.R. and S.K.O. drafted the manuscript; S.K.O., J.W. (Juan Wen), L.X. and Y.C. generated the figures and tables; S.K.O., S.W., J.W. (Jianchen Wang) and L.S. discussed literatures; Z.R., S.K.O., S.C., S.Y. and X.M. designed the work, drafted and revised the manuscript, J.D. and Y.H. supervised and funded the paper. All authors have read and agreed to the published version of the manuscript.

Funding: This research was supported by the Sichuan Province Science and Technology Support Program (Grant No. 2020YFS0337).

Data Availability Statement: Not applicable.

Acknowledgments: I would like to thank all authors for their hard work in making this paper publishable. I also send my sincere gratitude to the teaching staff of the college of veterinary medicine, Sichuan Agricultural University, Chengdu, for their advice and guidance in writing this paper.

Conflicts of Interest: The authors declare no conflict of interest.

\section{References}

1. Nie, X.; Lv, S.; Zhang, Y.; Du, X.; Wang, L.; Biradar, S.S.; Tan, X.; Wan, F.; Weining, S. Complete Chloroplast Genome Sequence of a Major Invasive Species, Crofton Weed (Ageratina adenophora). PLoS ONE 2012, 7, e36869. [CrossRef] [PubMed]

2. Zhang, K.M.; Liu, J.H.; Cheng, X.; Zhang, G.F.; Fang, Y.M.; Zhang, H.J. Effects of Ageratina adenophora on Spore Germination and Gametophyte Development of Neocheiropteris palmatopedata. Am. Fern J. 2012, 102, 208-215. [CrossRef]

3. Sun, W.; Zeng, C.; Yue, D.; Liu, S.; Ren, Z.; Zuo, Z.; Deng, J.; Peng, G.; Hu, Y. Ageratina adenophora causes spleen toxicity by inducing oxidative stress and pyroptosis in mice. R. Soc. Open Sci. 2019, 6, 190127. [CrossRef] [PubMed] 
4. Sharma, D.; Mal, G.; Kannan, A.; Bhar, R.; Sharma, R.; Singh, B. Degradation of euptox A by tannase-producing rumen bacteria from migratory goats. J. Appl. Microbiol. 2017, 123, 1194-1202. [CrossRef] [PubMed]

5. O'Sullivan, B.M. Investigations into Crofton weed (Eupatorium adenophorum) toxicity in horses. Aust. Vet. J. 1985, 62, 30-32. [CrossRef]

6. Verma, A.; Yadava, B.P.S.; Sampath, K.T. Possible Use of Eupatorium adenophorum Spreng. in Animal Feeding. Indian J. Anim. Nutr 1987, 4, 189-192.

7. Oelrichs, P.B.; Calanasan, C.A.; Macleod, J.K.; Seawright, A.A.; Ng, J.C. Isolation of a compound from Eupatorium adenophorum (Spreng.) [Ageratina adenophora (Spreng.)] causing hepatotoxicity in mice. Nat. Toxins 1995, 3, 350-354. [CrossRef]

8. Kaushal, V.; Dawra, R.K.; Sharma, O.P.; Kurade, N.P. Biochemical Alterations in the Blood Plasma of Rats Associated with Hepatotoxicity Induced by Eupatorium adenophorum. Vet. Res. Commun. 2001, 25, 601-608. [CrossRef] [PubMed]

9. He, Y.; Chen, W.; Hu, Y.; Luo, B.; Wu, L.; Qiao, Y.; Mo, Q.; Xu, R.; Zhou, Y.; Ren, Z.; et al. E. adenophorum Induces Cell Cycle and Apoptosis of Renal Cells through Mitochondrial Pathway and Caspase Activation in Saanen Goat. PLoS ONE 2015, 10, e0138504. [CrossRef] [PubMed]

10. He, Y.; Mo, Q.; Hu, Y.; Chen, W.; Luo, B.; Wu, L.; Qiao, Y.; Xu, R.; Zhou, Y.; Zuo, Z.; et al. E. adenophorum induces Cell Cycle Arrest and Apoptosis of Splenocytes through the Mitochondrial Pathway and Caspase Activation in Saanen Goats. Sci. Rep. 2015, 5, 15967. [CrossRef] [PubMed]

11. He, Y.; Mo, Q.; Hu, Y.; Luo, B.; Wei, Y. Induction of Apoptosis and Autophagy via Mitochondria- and PI3K/Akt/mTOR-mediated Pathways by E. adenophorum in Hepatocytes of Saanen Goat. Oncotarget 2016, 7, 54537-54548. [CrossRef]

12. Singh, Y.D.; Mukhopadhayay, S.K.; Shah, M.A.A.; Ali, M.A.; Tolenkhomba, T.C. Effects of Eupatorium ade-nophorum on Antioxidant Enzyme Status in a Mice Model. Int. J. Pharm. Pharm. Sci. 2012, 4, 436-439.

13. Ouyang, C.-B.; Liu, X.-M.; Yan, D.-D.; Li, Y.; Wang, Q.-X.; Cao, A.-C.; Guo, M.-X. Immunotoxicity assessment of cadinene sesquiterpenes from Eupatorium adenophorum in mice. J. Integr. Agric. 2016, 15, 2319-2325. [CrossRef]

14. Sun, W.; Zeng, C.-R.; Yue, D.; Hu, Y.-C. Involvement of mitochondrial dysfunction in hepatotoxicity induced by Ageratina adenophora in mice. J. Zhejiang Univ. Sci. B 2019, 20, 693-698. [CrossRef]

15. Sang, W.; Zhu, L.; Axmacher, J. Invasion pattern of Eupatorium adenophorum Spreng in southern China. Biol. Invasions 2009, 12, 1721-1730. [CrossRef]

16. Wang, C.; Lin, H.; Feng, Q.; Jin, C.; Cao, A.; He, L. A New Strategy for the Prevention and Control of Eupatorium adenophorum under Climate Change in China. Sustainability 2017, 9, 2037. [CrossRef]

17. Hui, L.; Sheng, Q.; Yaling, Q. Physiological Response of Different Croftonweed (Eupatorium adenophorum) Popula-tions to Low Temperature. Weed Sci. 2008, 2, 196-202.

18. Sun, W.; Zeng, C.; Liu, S.; Fu, J.; Hu, L.; Shi, Z.; Yue, D.; Ren, Z.; Zhong, Z.; Zuo, Z.; et al. Ageratina adenophora induces mice hepatotoxicity via ROS-NLRP3-mediated pyroptosis. Sci. Rep. 2018, 8, 16032. [CrossRef]

19. Auld, B.A. The distribution of Eupatorium adenophorum Spreng. on the far north coast of New South Wales. J. Proc. R. Soc. N. S. W. 1969, 102, 159-161.

20. Lu, P.; Sang, W.G.; Ma, K.P. Progress and prospects in research of an exotic invasive species, Eupatorium adenophorum. Acta Phytoecol. Sin. 2005, 29, 1029-1037.

21. Wang, C.; Liu, W.; Liu, L.; Cui, J. Plant diversity of different replaced communities after Eupatorium adenophorum removal. Ying Yong Sheng Tai Xue Bao J. Appl. Ecol. 2006, 17, 377-383.

22. Tripathi, Y.; Saini, N.; Anjum, N.; Verma, P. A review of Ethnomedicinal, Phytochemical, Pharmacological and Toxicological Aspects of Eupatorium adenophorum Spreng. Asian J. Biomed. Pharm. Sci. 2018, 8, 25-35.

23. Wolff, M.A. Winning the War of Weeds: The Essential Gardener's Guide to Weed Identification and Control; Kangaroo Press: Ken-thurst, NSW, Australia, 1999; p. 17.

24. Scher, J. Federal Noxious Weed Disseminules of the U.S.: An Interactive Identification Tool for Seeds and Fruit of Plants on the United States Federal Noxious Weed List, CDROM; Animal and Plant Health Inspection Service (APHIS), United States Department of Agriculture (USDA): CA, USA, 2005.

25. Cronk, Q.C.B.; Fuller, J.L. Plant Invaders: The Threat to Natural Ecosystems; Chapman \& Hall: London, UK, 1995.

26. Zárybnický, T.; Boušová, I.; Ambrož, M.; Skálová, L. Hepatotoxicity of Monoterpenes and Sesquiterpenes. Arch. Toxicol. 2018, 92, 1-13. [CrossRef]

27. Ouyang, C.; Liu, X.; Liu, Q.; Bai, J.; Li, H.; Li, Y.; Wang, Q.; Yan, D.; Mao, L.; Cao, A.; et al. Toxicity Assessment of Cadinene Sesquiterpenes from Eupatorium adenophorum in Mice. Nat. Prod. Bioprospect. 2014, 5, 29-36. [CrossRef]

28. Bai, J.; Cao, A.; Guo, M.; Liu, X.; Liu, X.; Liang, H.; Zhou, B. Identification of 9-oxo-10,11-dehydroagerophorone in Eupatorium adenophorum by HPLC. Chin. Bull. Bot. 2011, 46, 470-475.

29. Okyere, S.K.; Wen, J.; Cui, Y.; Xie, L.; Gao, P.; Wang, J.; Wang, S.; Hu, Y. Toxic mechanisms and pharmacological properties of euptox A, a toxic monomer from A. adenophora. Fitoteapia 2021, 155, 105032. [CrossRef]

30. Bhardwaj, R.; Singh, A.; Sharma, O.P.; Dawra, R.K.; Kurade, N.P.; Mahato, S.B. Hepatotoxicity and Cholestasis in Rats Induced by the Sesquiterpene, 9-oxo-10,11-dehydroageraphorone, Isolated from Eupatorium adenophorum. J. Biochem. Mol. Toxicol. 2001, 15, 279-286. [CrossRef] 
31. Mo, Q.; Hu, L.; Weng, J.; Zhang, Y.; Zhou, Y.; Xu, R.; Zuo, Z.; Deng, J.; Ren, Z.; Zhong, Z.; et al. Euptox A induces G1 Arrest and Autophagy via P38 MAPK- and PI3K/Akt/mTOR-mediated Pathways in Mouse Splenocytes. J. Histochem. Cytochem. 2017, 65, 543-558. [CrossRef]

32. Okyere, S.K.; Mo, Q.; Pei, G.; Ren, Z.; Deng, J.; Hu, Y. Euptox A Induces G0/GI Arrest and Apoptosis of Hepato-cyte via ROS, Mitochondrial Dysfunction and Caspases-dependent Pathways in vivo. J. Toxicol. Sci. 2020, 45, 661-671. [CrossRef]

33. Ren, Z.; Gao, P.; Okyere, S.; Cui, Y.; Wen, J.; Jing, B.; Deng, J.; Hu, Y. Ageratina adenophora Inhibits Spleen Immune Function in Rats via the Loss of the FRC Network and Th1-Th2 Cell Ratio Elevation. Toxins 2021, 13, 309. [CrossRef]

34. Hosseini, M.J.; Shaki, F.; Ghazi-Khansari, M.; Pourahmad, J. Toxicity of Arsenic (III) on Isolated Liver Mitochondria: A New Mechanistic Approach. Iran. J. Pharm. Res. 2013, 12, 119-136.

35. Fu, J.; Hu, Y.; Chen, W.; Weng, J.; Hu, L.; Wen, S. Dosage-dependent Effects of Eupatorium adenophorum on Saanen Goat Blood Levels and the Histopathology of Several Organs. Pratacult. Sci. 2018, 35, 434-440.

36. Irazabal, M.V.; Torres, V.E. Reactive Oxygen Species and Redox Signaling in Chronic Kidney Disease. Cells 2020, 9, 1342. [CrossRef] [PubMed]

37. Chelombitko, M.A. Role of Reactive Oxygen Species in Inflammation: A Minireview. Mosc. Univ. Biol. Sci. Bull. 2018, 73, 199-202. [CrossRef]

38. Liu, Z.; Lu, G.; Xu, Y.; Luo, D.; Ren, Q.; Wu, S.; Sun, C. Melatonin Alleviates Inflammasome-Induced Pyroptosis Through Inhibiting NF-кB/GSDMD Signal in Mice Adipose Tissue. J. Pineal Res. 2017, 29, e12414. [CrossRef]

39. Jorgensen, I.; Rayamajhi, M.; Miao, E.A. Programmed cell death as a defence against infection. Nat. Rev. Immunol. 2017, 17, 151-164. [CrossRef]

40. Liu, Z.; Yao, X.; Jiang, W.; Li, W.; Zhu, S.; Liao, C.; Zou, L.; Ding, R.; Chen, J. Advanced Oxidation Protein Products Induce Micro-glia-mediated Neuroinflammation via MAPKs-NF-кB Signaling Pathway and Pyroptosis after Secondary Spinal Cord Injury. J. Neuroinflamm. 2020, 17, 90. [CrossRef]

41. Boucher, D.; Chan, A.; Ross, C.; Schroder, K. Quantifying Caspase-1 Activity in Murine Macrophages. Clin. Appl. Mass Spectrom. Biomol. Anal. 2018, 1725, 163-176. [CrossRef]

42. Kuriakose, T.; Kanneganti, T.-D. Pyroptosis in Antiviral Immunity. Curr. Top. Microbiol. Immunol. 2019, 10, 1-19. [CrossRef]

43. Qian, Z.; Zhao, Y.; Wan, C.; Deng, Y.; Zhuang, Y.; Xu, Y.; Zhu, Y.; Lu, S.; Bao, Z. Pyroptosis in the Initiation and Progression of Atherosclerosis. Front. Pharmacol. 2021, 12, 652963. [CrossRef] [PubMed]

44. Yu, P.; Zhang, X.; Liu, N.; Tang, L.; Peng, C.; Chen, X. Pyroptosis: Mechanisms and diseases. Signal. Transduct. Target. Ther. 2021, 6,1-21. [CrossRef] [PubMed]

45. Lin, J.; Cheng, A.; Cheng, K.; Deng, Q.; Zhang, S.; Lan, Z.; Wang, W.; Chen, J. New Insights into the Mechanisms of Pyroptosis and Implications for Diabetic Kidney Disease. Int. J. Mol. Sci. 2020, 21, 7057. [CrossRef]

46. Lu, F.; Lan, Z.; Xin, Z.; He, C.; Guo, Z.; Xia, X.; Hu, T. Emerging insights into molecular mechanisms underlying pyroptosis and functions of inflammasomes in diseases. J. Cell. Physiol. 2020, 235, 3207-3221. [CrossRef] [PubMed]

47. Cui, Y.; Okyere, S.K.; Gao, P.; Wen, J.; Cao, S.; Wang, Y.; Deng, J.; Hu, Y. Ageratina adenophora Disrupts the Intestinal Structure and Immune Barrier Integrity in Rats. Toxins 2021, 13, 651. [CrossRef] [PubMed]

48. Ahluwalia, V.; Sisodia, R.; Walia, S.; Sati, O.P.; Kular, J.; Kundu, A. Chemical Analysis of Essential Oils of Eupatorium adenophorum and Their Antimicrobial, Antioxidant and Phytotoxic Properties. J. Pest. Sci. 2014, 87, 341-349. [CrossRef]

49. Sharma, O.P.; Dawra, R.K.; Kurade, N.P.; Sharma, P.D. A Review of the Toxicosis and Biological Properties of the genus Eupatorium. Nat. Toxins 1998, 6, 1-14. [CrossRef]

50. Awah, F.M.; Uzoegwu, P.N.; Ifeonu, P.; Oyugi, J.O.; Rutherford, J.; Yao, X.; Fehrmann, F.; Fowke, K.; Eze, M.O. Free radical scavenging activity, phenolic contents and cytotoxicity of selected Nigerian medicinal plants. Food Chem. 2012, 131, 1279-1286. [CrossRef]

51. Fu, J.; Hu, L.; Shi, Z.; Wei, S.; Dong, Y.; Ya, W.; Ma, X.; Ren, Z.; Zuo, Z.; Peng, G.; et al. Two metabolites isolated from endophytic fungus Coni-ochaeta sp. F-8 in Ageratina adenophora exhibit antioxidative activity and cytotoxicity. Nat. Prod. Res. 2019, 35, 2840-2848. [CrossRef] [PubMed]

52. Xu, R.; Weng, J.; Hu, L.; Peng, G.; Ren, Z.; Deng, J.; Jia, Y.; Wang, C.; He, H.; Hu, Y. Anti-NDV activity of 9-oxo10,11dehydroageraphorone extracted from Eupatorium adenophorum Spreng in vitro. Nat. Prod. Res. 2017, 32, 2244-2247. [CrossRef] [PubMed]

53. Nong, X.; Ren, Y.-J.; Wang, J.-H.; Xie, Y.; Fang, C.-L.; Yang, D.-Y.; Liu, T.-F.; Zhang, R.-H.; Chen, L.; Gu, X.-B.; et al. Clinical efficacy of botanical extracts from Eupatorium adenophorum against the Sarcoptes scabiei (Sarcoptidae: Sarcoptes) in rabbits. Vet. Parasitol. 2013, 195, 157-164. [CrossRef]

54. Rajeswary, M.; Govindarajan, M.; Murugan, K.; Hwang, J.S.; Barnard, D.R.; Amsath, A.; Muthukumaran, U. Ovicidal Efficacy Of Ageratina adenophora (Family:Asteraceae) against Anopheles Stephensi (Diptera: Culicidae). Int. J. Pure Appl. Zool. 2014, 2, 196-199.

55. Das, R. Antifungal activities and phytochemical screening of two invasive alien species of Nepal. Stud. Fungi $2018,3,293-301$. [CrossRef]

56. Pandey, A.K.; Mohan, M.; Singh, P.; Palni, U.T.; Tripathi, N. Chemical composition, antibacterial and antioxidant activity of essential oil of Eupatorium adenophorum Spreng. from Eastern Uttar Pradesh, India. Food Biosci. 2014, 7, 80-87. [CrossRef]

57. Arvind, N.; Amit, S. Antimicrobial Potential of Eupatorium adenophorum Spreng. Phcog. J. 2010, 2, 61-64. 
58. Ramya, N.; Mayuri, P.K.; Santny, A.S.; Angayarkanni, T. Antimicrobial efficacy of silver nanoparticles conju-gated with Ageratina adenophora leaf extract. Asia Pac. J. Res. 2015, 1, 170-176.

59. Liu, X.; Ouyang, C.; Li, Y.; Yang, D.; Fang, W.; Yan, D.; Guo, M.; Cao, A.; Wang, Q. Evaluation of the antimicrobial activity of 9-oxo-agerophorone against soil borne pathogens. J. Plant Dis. Prot. 2016, 123, 163-170. [CrossRef]

60. Dong, L.-M.; Zhang, M.; Xu, Q.-L.; Zhang, Q.; Luo, B.; Luo, Q.-W.; Liu, W.-B.; Tan, J.-W. Two New Thymol Derivatives from the Roots of Ageratina adenophora. Molecules 2017, 22, 592. [CrossRef]

61. Kundu, A.; Saha, S.; Walia, S.; Shakil, N.A.; Kumar, J.; Annapurna, K. Cadinene sesquiterpenes from Eupatorium adenophorum and their antifungal activity. J. Environ. Health B 2013, 48, 516-522. [CrossRef]

62. Zheng, G.; Luo, S.; Li, S.; Hua, J.; Li, W.; Li, S. Specialized metabolites from Ageratina adenophora and their inhibitory activities against pathogenic fungi. Phytochemistry 2018, 148, 57-62. [CrossRef] [PubMed]

63. Zhao, C.; Wang, Y.; Liu, R.; Xie, X. Study on the inhibitory effect of Eupatorium adenophorum extract on two plant pathogenic fungi. Hubei Agric. Sci. 2012, 51, 1133-1135.

64. Liu, B.; Cao, L.; Zhang, L.; Yuan, X.; Zhao, B. Preparation, Phytochemical Investigation, and Safety Evaluation of Chlorogenic Acid Products from Eupatorium adenophorum. Molecules 2016, 22, 67. [CrossRef]

65. Liu, X.; Ouyang, C.; Wang, Q.; Li, Y.; Yan, D.; Yang, D.; Guo, M.; Cao, A. Evaluation of antibacterial and anti-fungal properties of 9-oxo-10,11-dehydroageraphorone extracted from Eupatorium adenophorum. J. Plant Dis. Prot. 2016, 123, 93-99. [CrossRef]

66. Hu, L.; Hu, Y.; Zhang, Y.; Shi, Z.; Fu, J.; Sun, W.; Deng, J.; Ren, Z.; Zuo, Z.; Cao, S.; et al. Inhibition effect of Ageratina adenophora is methanol extracts against Microsporidium gypsum and its mechanism. Acta Agric. Zhejiangensis 2019, 31, $1555-1562$.

67. Liu, X.; Ouyang, C.; Wang, Q.; Li, Y.; Yan, D.; Yang, D.; Fang, W.; Cao, A.; Guo, M. Effects of oil extracts of Eupatorium adenophorum on Phytophthora capsici and other plant pathogenic fungi in vitro. Pestic Biochem. Physiol. 2017, 140, 90-96. [CrossRef]

68. Lin, Y.; He, S.-Q.; Lu, Z.-H.; Gao, Y.-L.; Duan, Y.-R.; Li, Z.-Y.; Chen, B.; Gui, F.-R. Influence of Aphis gossypii feeding on defense strategy of native and introduced populations of Ageratina adenophora. Arthropod-Plant Interact. 2020, 14, 345-356. [CrossRef]

69. Xu, R.; Wu, D.; Zhang, W.D.; Yin, F.; Kuang, R.P. Efficacy of Ageratina adenophora extract and biogas fermentation residue against the cabbage aphid, Brevicoryne brassicae and an assessment of the risk to the parasi-toid Diaeretiella rapae. Int. J. Pest Manag. 2009, 55, 151-156. [CrossRef]

70. Wang, Y. The toxicities of the extracts from Eupatorium adenophorum against Aphis gossypii and their aphid-killing mechanism. J. Plant Prot. 2002, 29, 337-340.

71. André, R.; Catarro, J.; Freitas, D.; Pacheco, R.; Oliveira, M.C.; Serralheiro, M.L.; Falé, P.L. Action of Euptox A from Ageratina adenophora Juice on Human Cell Lines: A Top-down Study Using FTIR Spectroscopy and Protein Profiling. Toxicol. Vitr. 2019, 57, 217-225. [CrossRef]

72. Liao, F.; Wang, Y.; Huang, Y.; Mo, Q.; Tan, H.; Wei, Y.; Hu, Y. Isolation and identification of bacteria capable of degrading euptox A from Eupatorium adenophorum Spreng. Toxicon 2014, 77, 87-92. [CrossRef]

73. Chen, H.; Zhou, B.; Yang, J.; Ma, X.; Deng, S.; Huang, Y.; Wen, Y.; Yuan, J.; Yang, X. Essential Oil Derived from Eupatorium adenophorum Spreng. Mediates Anticancer Effect by Inhibiting STAT3 and AKT Activation to Induce Apoptosis in Hepatocellular Carcinoma. Front. Pharmacol. 2018, 9, 483. [CrossRef]

74. Ringmichon, C.L.; Gopalkrishnan, B. Antipyretic activity of Eupatorium adenophorum leaves. Int. J. Appl. Biol. Pharm. 2017, 8, 1-4.

75. Mandal, P.; Sinha Babu, S.P.; Mandal, N.C. Antimicrobial Activity of Saponins from Acacia auriculiformis. Fitoterapia 2005, 76, 462-465. [CrossRef]

76. Kumar, N.; Singh, A.; Sharma, D.K.; Kishore, K. Evaluation of wound healing activity of Ageratina adenophora (Spreng.) R. M. King \& H. Rob. Int. J. Pharma Res. Health Sci. 2017, 5, 1873-1876.

77. Tiwary, B.K.; Bihani, S.; Kumar, A.; Chakraborty, R.; Ghosh, R. The In Vitro Cytotoxic Activity of Eth-no-pharmacological Important Plants of Darjeeling District of West Bengal against Different Human Cancer Cell Lines. BMC Complement. Altern. Med. 2015, 15, 22. [CrossRef]

78. Palá-Paúl, J.; Pérez-Alonso, M.; Velasco-Negueruela, A.; Sanz, J. Analysis by gas chromatography-mass spectrometry of the volatile components of Ageratina adenophora Spreng.; growing in the Canary Islands. J. Chromatogr. A 2002, 947, 327-331. [CrossRef]

79. Khazeo, P.; Mazumder, M.U.; Puro, K.N.; Jyrwa, R.; Jamir, N.; Sailo, L. In vitro Antioxidant Activity of Methanolic Extracts of Ageratum conyzoides and Ageratina adenophora Leaves. Perspect. Trends Dev. Sci. Educ. Res. 2018, 178, 169-172.

80. Amevor, F.K.; Cui, Z.; Du, X.; Ning, Z.; Shu, G.; Jin, N.; Deng, X.; Tian, Y.; Zhang, Z.; Kang, X.; et al. Combination of Quercetin and Vitamin E Supple-mentation Promotes Yolk Precursor Synthesis and Follicle Development in Aging Breeder Hens via Liver-Blood-Ovary Signal Axis. Animals 2021, 11, 1915. [CrossRef] [PubMed]

81. Kim, E.N.; Lim, J.H.; Kim, M.Y.; Ban, T.H.; Jang, I.A.; Yoon, H.E.; Park, C.W.; Chang, Y.S.; Choi, B.S. Resveratrol, an Nrf2 activator, Ameliorates Aging-related Progressive Renal Injury. Aging 2018, 10, 83-99. [CrossRef]

82. Zhao, Q.; Yang, F.; Meng, L.; Chen, D.; Wang, M.; Lu, X.; Chen, D.; Jiang, Y.; Xing, N. Lycopene attenuates chronic prostatitis/chronic pelvic pain syndrome by inhibiting oxidative stress and inflammation via the interaction of NF- $\mathrm{kB}, \mathrm{MAPKs}$, and Nrf2 signaling pathways in rats. Andrology 2020, 8, 747-755. [CrossRef] [PubMed]

83. Yue, D.; Zeng, C.; Okyere, S.K.; Chen, Z.; Hu, Y. Glycine nano-selenium prevents brain oxidative stress and neurobehavioral abnormalities caused by MPTP in rats. J. Trace Elements Med. Biol. 2021, 64, 126680. [CrossRef] [PubMed]

84. Cui, Y.; Liu, B.; Sun, X.; Li, Z.; Chen, Y.; Guo, Z.; Liu, H.; Li, D.; Wang, C.; Zhu, X.; et al. Protective effects of alfalfa saponins on oxidative stress-induced apoptotic cells. Food Funct. 2020, 11, 8133-8140. [CrossRef] 
85. Li, F.; Xiang, H.; Lu, J.; Chen, Z.; Huang, C.; Yuan, X. Lycopene ameliorates PTSD-like behaviors in mice and rebalances the neuroinflammatory response and oxidative stress in the brain. Physiol. Behav. 2020, 224, 113026. [CrossRef] [PubMed]

86. Cheng, C.; Zou, Y.; Peng, J. Oregano Essential Oil Attenuates RAW264.7 Cells from Lipopolysaccharide-Induced Inflammatory Response through Regulating NADPH Oxidase Activation-Driven Oxidative Stress. Molecules 2018, 23, 1857. [CrossRef] [PubMed]

87. Sun, X.; Feng, X.; Zheng, D.; Li, A.; Li, C.; Li, S.; Zhao, Z. Ergosterol attenuates cigarette smoke extract-induced COPD by modulating inflammation, oxidative stress and apoptosis in vitro and in vivo. Clin. Sci. 2019, 133, 1523-1536. [CrossRef]

88. Kulkarni, R.A.; Deshpande, A.R. Anti-inflammatory and antioxidant effect of ginger in tuberculosis. J. Complement. Integr. Med. 2016, 13, 201-206. [CrossRef]

89. Huang, H.; Li, X.; Wang, Z.; Lin, X.; Tian, Y.; Zhao, Q.; Zheng, P. Anti-inflammatory effect of selenium on lead-induced testicular inflammation by inhibiting NLRP3 inflammasome activation in chickens. Theriogenology 2020, 155, 139-149. [CrossRef]

90. De Marco, S.; Sichetti, M.; Muradyan, D.; Piccioni, M.; Traina, G.; Pagiotti, R.; Pietrella, D. Probiotic Cell-Free Supernatants Exhibited Anti-Inflammatory and Antioxidant Activity on Human Gut Epithelial Cells and Macro-phages Stimulated with LPS. Evid. Based Complement. Altern. Med. 2018, 2018, 1756308. [CrossRef] [PubMed]

91. Poudel, R.; Neupane, N.P.; Mukeri, I.H.; Alok, S.; Verma, A. An updated review on invasive nature, phyto-chemical evaluation, \& pharmacological activity of Ageratina adenophora. Int. J. Pharm. Sci. Res. 2020, 11, 2510-2520.

92. Chakravarty, A.K.; Mazumder, T.; Chatterjee, S.N. Anti-Inflammatory Potential of Ethanolic Leaf Extract of Eupatorium adenophorum Spreng. Through Alteration in Production of TNF- $\alpha$, ROS and Expression of Certain Genes. Evid. Based Complement. Altern. Med. 2011, 2011, 471074. [CrossRef]

93. Singh, B.; Mal, G.; Marotta, F. Designer Probiotics: Paving the Way to Living Therapeutics. Trends Biotechnol. 2017, 35, 679-682. [CrossRef] [PubMed]

94. Chettri, B.; Singha, N.A.; Mukherjee, A.; Rai, A.N.; Chattopadhyay, D.; Singh, A.K. Hydrocarbon Degradation Potential and Competitive Persistence of Hydrocarbonoclastic Bacterium Acinetobacter pittii strain ABC. Arch. Microbiol. 2019, 201, 1129-1140. [CrossRef]

95. Hashmat, A.J.; Afzal, M.; Fatima, K.; Anwar-Ul-Haq, M.; Khan, Q.M.; Arias, C.A.; Brix, H. Characterization of HydrocarbonDegrading Bacteria in Constructed Wetland Microcosms Used to Treat Crude Oil Polluted Water. Bull. Environ. Contam. Toxicol. 2019, 102, 358-364. [CrossRef] [PubMed]

96. Risa, A.; Krifaton, C.; Kukolya, J.; Kriszt, B.; Cserháti, M.; Táncsics, A. Aflatoxin B1 and Zearalenone-Detoxifying Profile of Rhodococcus Type Strains. Curr. Microbiol. 2018, 75, 907-917. [CrossRef] [PubMed]

97. Żółkiewicz, J.; Marzec, A.; Ruszczyński, M.; Feleszko, W. Postbiotics-A Step Beyond Pre- and Probiotics. Nutrients 2020, $12,2189$. [CrossRef]

98. Han, K.J.; Lee, J.E.; Lee, N.K.; Paik, H.D. Antioxidant and Anti-Inflammatory Effect of Probiotic Lactobacillus plantarum KU15149 Derived from Korean Homemade Diced-Radish Kimchi. J. Microbiol. Biotechnol. 2020, 30, 591-598. [CrossRef] [PubMed]

99. de Souza, M.; Baptista, A.A.S.; Valdiviezo, M.J.J.; Justino, L.; Menck-Costa, M.F.; Ferraz, C.R.; da Gloria, E.M.; Verri, W.A., Jr.; Bracarense, A.P.F. Lactobacillus spp. reduces morphological changes and oxidative stress induced by deoxynivalenol on the intestine and liver of broilers. Toxicon 2020, 185, 203-212. [CrossRef] [PubMed]

100. Lee, T.; Park, D.; Kim, Y.J.; Lee, I.; Kim, S.; Oh, C.; Kim, J.; Yang, J.; Jo, S. Lactobacillus salivarius BP121 prevents cisplatin-induced acute kidney injury by inhibition of uremic toxins such as indoxyl sulfate and p-cresol sulfate via alleviating dysbiosis. Int. J. Mol. Med. 2020, 45, 1130-1140. [CrossRef]

101. Fernández, J.; Silván, B.; Entrialgo-Cadierno, R.; Villar, C.J.; Capasso, R.; Uranga, J.A.; Lombó, F.; Abalo, R. Antiproliferative and palliative activity of flavonoids in colorectal cancer. Biomed. Pharmacother. 2021, 143, 112241. [CrossRef] [PubMed]

102. Martínez, V.; Iriondo De-Hond, A.; Borrelli, F.; Capasso, R.; Del Castillo, M.D.; Abalo, R. Cannabidiol and Other Non-Psychoactive Cannabinoids for Prevention and Treatment of Gastrointestinal Disorders: Useful Nutraceuticals? Int. J. Mol. Sci. 2020, $21,3067$. [CrossRef]

103. Freitas, M.; Vasconcelos, A.; Gonçalves, E.; Ferrarini, E.; Vieira, G.; Cicia, D.; Cola, M.; Capasso, R.; Dutra, R. Involvement of Opioid System and TRPM8/TRPA1 Channels in the Antinociceptive Effect of Spirulina platensis. Biomolecules 2021, 11, 592. [CrossRef] 